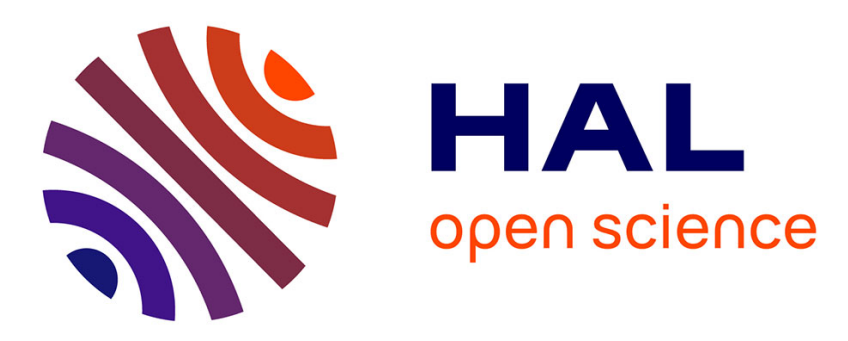

\title{
Thermal trapped iron(II) high spin state investigated by $\mathrm{X}$-ray diffraction
}

\author{
Mathieu Marchivie, Philippe Guionneau, Jean-François Létard, Daniel
}

Chasseau, Judith A. K. Howard

\section{To cite this version:}

Mathieu Marchivie, Philippe Guionneau, Jean-François Létard, Daniel Chasseau, Judith A. K. Howard. Thermal trapped iron(II) high spin state investigated by X-ray diffraction. Journal of Physics and Chemistry of Solids, 2004, 65 (1), pp.17-23. 10.1016/j.jpcs.2003.09.002 . hal-00135950

\section{HAL Id: hal-00135950 https://hal.science/hal-00135950}

Submitted on 13 Jul 2007

HAL is a multi-disciplinary open access archive for the deposit and dissemination of scientific research documents, whether they are published or not. The documents may come from teaching and research institutions in France or abroad, or from public or private research centers.
L'archive ouverte pluridisciplinaire HAL, est destinée au dépôt et à la diffusion de documents scientifiques de niveau recherche, publiés ou non, émanant des établissements d'enseignement et de recherche français ou étrangers, des laboratoires publics ou privés. 


\title{
Thermal trapped iron(II) high spin state investigation by x-ray diffraction
}

\author{
Marchivie M., Guionneau P., Létard J.-F., Chasseau D., Howard J. A. K.
}

\section{INTRODUCTION}

In iron(II) complexes the conversion from a paramagnetic state (high spin, HS) to a diamagnetic state (low spin, LS) may be triggered by external perturbations (temperature, pressure, light irradiation, magnetic field) [1 and 2]. Such a phenomenon, called spin crossover (SCO) is widely studied either for the fundamental problems it raises or the potential industrial applications it offers. In the solid state, the features of the SCO can be notably different from one complex to the other: large range of critical temperature ( $T_{1 / 2}$ from a few $\mathrm{K}$ to above room temperature), abrupt, gradual, complete, incomplete or multi-steps transitions. The effects of temperature and light on iron(II) complexes have been and are still carefully investigated in order to obtain, for example, a large panel of temperatures and features of transition to offer series of complexes with characteristics "à la carte" to answer practical application requirements [3]. As a general matter of fact, the features of the magnetic behaviour are known to depend strongly on intrinsic properties of the complexes and also on structural properties such as for example the intermolecular hydrogen bonding or $\pi-\pi$ stacks interactions. In order to understand the magneto-structural relationship, one of our objectives is to correlate the structural properties, determined in various environments $(T, P, h v)$, to the magnetic behaviour.

Indeed, we have been focusing for a few years on the iron(II) SCO family of general formula $\left.\left[\mathrm{Fe}(\mathrm{PM}-\mathrm{L})_{2} \text { (NCS }\right)_{2}\right]$ for its diversity of magnetic and structural properties $[4,5,6,7$ and 8], $\mathrm{PM}=N$-2'-pyridylmethylene and $\mathrm{L}$ is an aromatic ligand (Fig. 1(a)). The structural properties have been determined and compared showing direct correlation between some intramolecular and intermolecular structural parameters and the features of the SCO. To reach such direct correlation the crystal structures were determined in the HS and LS spin states within the temperature range 10-300 K, high pressure data have aLSo been obtained. Additionally, the crystal structure of a complex in the light-induced metastable HS state was obtained in order to compare the effect of the temperature and the light irradiation on the material [9]. To delve further into the study of these iron(II) complexes and more generally into the interplay between structural properties and spin state, we investigate now the influence of the cooling rate on the structural properties and the SCO of these complexes. Indeed, the possibility that a HS state can be trapped by a rapid cooling is a feature to take into account in the development of practical application, such as for example temperature sensors, and must consequently be investigated.

In general, the study of metastable spin states is relevant to an understanding of the SCO phenomenon and in particular to the dynamics of the process. While the generation of light-induced metastable spin states, known as the LIESST (light-induced excited spin state trapping) effect, has been widely studied [10, 11 and 12], this is not the case of thermally trapped metastable spin states. Indeed, only a few investigations of the effects of the cooling rate on the SCO have already been reported [13, 14, 15, 16, 17, 18 and 19]. These previous studies have proved that, in some cases, a rapid cooling can trap the HS state with a HS $\rightarrow$ LS relaxation occurring afterwards. However, these studies mainly concerned the HS $\rightarrow$ LS relaxation process after $a$ rapid cooling, not a flash cooling (see Section 4 for definition), investigated by Mössbä̈er and/or magnetic susceptibility measurements techniques. Futhermore, the X-ray diffraction crystal structure of a complex in a trapped metastable state has not been reported so far; despite it being suspected in most cases that the trapped HS $\rightarrow$ LS relaxation is connected to the structural features [14, 16 and 18$]$.

The present paper reports the X-ray diffraction study of the flash cooled phase of one complex of the above iron(II) SCO series, the $\left[\mathrm{Fe}(\mathrm{PM}-\mathrm{BiA})_{2}(\mathrm{NCS})_{2}\right]$ complex, $\mathrm{BiA}=4$-(aminobiphenyl) (Fig. 1(b)).

\section{RESULTS AND DISCUSSIONS}

\subsection{The $\left[\mathrm{Fe}(\mathrm{PM}-\mathrm{L})_{2}(\mathrm{NCS})_{2}\right]$ complexes}

All the known complexes of the $\left[\mathrm{Fe}(\mathrm{PM}-\mathrm{L})_{2}(\mathrm{NCS})_{2}\right]$ family crystallise either in the orthorhombic space group Pccn or in the monoclinic space group $P_{2} /$ / . In both cases, the unit cell contains four molecules. In the orthorhombic packing (Fig. 2), the iron complexes lie on a two-fold axis and so are aligned in the $c$ direction. Within the $a b$ plane the neighbouring molecules are symmetrical about the screw axis and so lie in an antiparallel orientation. The monoclinic description is very close except that the iron complexes are not exactly aligned and the centres of adjacent molecules form a zigzag along $c$. Such a packing appears relatively compact in all cases and is driven by numerous $\pi-\pi$ interactions between neighbouring molecules within the $a b$ plane as well as intermolecular contacts, like weak hydrogen bonds of the kind S $\cdots \mathrm{H}-\mathrm{C}$ involving the NCS branches.

Within the above family, the $\left[\mathrm{Fe}(\mathrm{PM}-\mathrm{BiA})_{2}(\mathrm{NCS})_{2}\right]$ complex is of particular interest for the present study, first because its orthorhombic form shows an exceptionally abrupt spin conversion at $T_{1 / 2}=167 \mathrm{~K}$ [7], then because light irradiation may trigger 
a conversion from LS to HS at low temperature. The latter phenomenon, known as the LIESST effect [10], can be characterised by a limit temperature, which is noted $T$ (LIESST) and defined as the temperature for which the light-induced HS information is erased [20]. T(LIESST) is $78 \mathrm{~K}$ for this complex. The crystal structures of this complex are already known at $293 \mathrm{~K}$ (HS), $140 \mathrm{~K}$ (LS) and $30 \mathrm{~K}$ (LS) [5 and 7]. [Fe(PM-BiA $\left.)_{2}(\mathrm{NCS})_{2}\right]$ may crystallise in two polymorpHS; the first form, denoted I, crystallises in an orthorhombic system and the second form, denoted II, crystallises in a monoclinic system. The comparison of the magnetic and structural properties of both polymorpHS has already been reported [21]. The present paper only deaLS with the orthorhombic phase I.

\subsection{Unit cell parameters}

The crystallographic unit cell parameters modifications over a temperature range that includes the SCO reflects the contribution of both the pure thermal contraction and the effects of the SCO. Variable temperature X-ray diffraction studies are commonly used to estimate the true modifications due to the SCO only.

A general feature of the effect of the SCO on the crystallographic unit cell is a significant anisotropy of the unit cell modifications [22]. In the particular case of the orthorhombic phase of $\left[\mathrm{Fe}(\mathrm{PM}-\mathrm{BiA})_{2}(\mathrm{NCS})_{2}\right]$, it has been previously shown that unit cell changes due to the HS to LS SCO correspond to an increase of $c$, a decrease of $a$ and a slight decrease of $b$ [23]. Owing to such a characteristic modification, the spin state can be deduced, for this complex, directly from the unit cell changes. Comparison of the unit cell parameters at $30 \mathrm{~K}$ after a flash cooling or after a slow cooling clearly indicate the trap of the HS state by flash cooling ( Table 1). First, the comparison of the unit cell parameters at $30 \mathrm{~K}$ (HS) and $30 \mathrm{~K}$ (LS) confirms the anisotropy of the SCO effects on the structural properties; $c$ increases by around $0.5 \AA, a$ decreases by around $0.7 \AA$ and $b$ decreases by around $0.2 \AA$. Then, the comparison of the unit cell parameters at $293 \mathrm{~K}$ (HS) and $30 \mathrm{~K}$ (HS) shows the effect of the thermal contraction only. The thermal contraction strongly affects the b parameter and only very slightly $a$ and $c$.

The exact value of the unit cell volume change due to the $\mathrm{SCO}$ only, noted $\triangle \mathrm{V}_{S C}$, is a crucial information. In particular $\triangle \mathrm{V}_{S C}$ can be used in the calculation of the interaction energy between the molecules [24 and 25]. A rough value of $\triangle \mathrm{V}_{S C}$ is usually extracted from the temperature dependence of the unit cell parameters determined on a large temperature range by taking into account the contribution of the normal thermal contraction. The latter can, for example, be estimated from the comparison of the thermal contraction of isostructural complexes that do not present a SCO. The ideal situation, however, is when the unit cell dimensions are obtained in the HS and the LS states at the same temperature. Such is the case here. At $30 \mathrm{~K}$, the difference between the LS and the trapped HS states unit cell volume gives a $\triangle \mathrm{V}_{S C}$ of $160 \AA 3$ which corresponds to $4.5 \%$ of the room temperature volume. All the previously known $\triangle \mathrm{V}_{S C}$ values for the $\left[\mathrm{Fe}(\mathrm{PM}-\mathrm{L})_{2}(\mathrm{NCS})_{2}\right]$ complexes are in the range $1.5-4 \%$ of the room temperature volume [26]. Thus, polymorph I of [Fe(PM-BiA $\left.)_{2}(\mathrm{NCS})_{2}\right]$ presents the largest unit cell volume modification due to the SCO within this family. This result is perfectly in line with the exceptionally abrupt spin conversion for this compound.

The HS $\rightarrow$ LS relaxation after the thermal trapping at $30 \mathrm{~K}$ of $\left[\mathrm{Fe}(\mathrm{PM}-\mathrm{BiA})_{2}(\mathrm{NCS})_{2}\right]$ appears very slow for this complex, since after $16 \mathrm{~h}$ no significant change was observed on the Bragg intensities. Very long relaxation times were aLSo observed in the rapid cooling spectroSCOpic studies of $\left[\mathrm{Fe}(\mathrm{bpp})_{2}\left(\mathrm{BF}_{4}\right)_{2}\right][13]$ and $\left[\mathrm{Fe}(\mathrm{paptH})_{2}\right]\left(\mathrm{NO}_{3}\right)_{2}[16]$. However, in the latter cases, the very long relaxation time was suspected to indicate an interplay between the SCO and a crystallographic phase transition. In the present case of $\left[\mathrm{Fe}(\mathrm{PM}-\mathrm{BiA})_{2}(\mathrm{NCS})_{2}\right]$, the long relaxation time may be connected to the large gap between the HS and the LS unit celLS described above.

\subsection{Final temperature and thermal HS state trapping}

Can the HS state be trapped by flash cooling to any temperature below $\mathrm{T}_{1 / 2}$ ? In order to answer such a question we tried different final temperatures. The observation we made when the sample was flash cooled to $80 \mathrm{~K}$ deserves a particular remark. Fig. 3 shows the relative changes of the unit cell parameters at $80 \mathrm{~K}$ as a function of time after the sample has been flash cooled to $80 \mathrm{~K}$. First, the unit cell parameters are nearly constant and correspond to a HS unit cell. After a few minutes, the $c$ parameter increases by around $0.7 \AA, b$ decreases by $0.3 \AA$ and $a$ decreases by nearly $0.7 \AA$. This is the mark of the HS $\rightarrow$ LS conversion in this complex. Thus, the complex is in the HS state for a few minutes then it relaxes to the LS state. The $80 \mathrm{~K}$ HS unit cell volume $\left(3365(10) \AA^{3}\right.$ ) appears significantly different from the HS room temperature unit cell volume $\left(3481(2) \AA^{3}\right)$. This proves that the sample temperature is indeed $80 \mathrm{~K}$. Besides, after relaxation, the LS unit cell volume $\left(3255(2) \AA^{3}\right)$ is identical to the LS unit cell volume obtained after a slow cooling $\left(3260(2) \AA^{3}\right)$. Clearly, at this temperature, the HS state is trapped for a few minutes. Then relaxation to the LS occurs.

When the sample is flash cooled from room temperature to a temperature higher than $80 \mathrm{~K}$, no HS trapping is observed, at least at the time scale of a few seconds. Conversely, when the sample is flash cooled to a temperature lower than 80(2) K, the HS is trapped and stable for, at least, a few hours. Consequently, it clearly appears that, for polymorph I of $\left[\mathrm{Fe}(\mathrm{PM}-\mathrm{BiA})_{2}(\mathrm{NCS})_{2}\right]$, the HS is trapped by flash cooling only if the final temperature is lower than $80(2) \mathrm{K}$. Interestingly this temperature is close to the $T$ (LIESST) temperature for this complex $(78(1) \mathrm{K})$ determined by light irradiation effect. 
To further investigate this point, we have tested the possibility of trapping the HS state by flash cooling in one of the more studied iron(II) complex, [Fe(phen $\left.)_{2}(\mathrm{NCS})_{2}\right][26$ and 27], PHEN=1,10-phenantroline. The interesting features of this compound are that the $T$ (LIESST), $62 \mathrm{~K}$, is of the same order of magnitude than for the polymorph I of $\left[\mathrm{Fe}(\mathrm{PM}-\mathrm{BiA})_{2}(\mathrm{NCS})_{2}\right]$ and that it is the only $\mathrm{FeL}_{n}(\mathrm{NCS})_{2}$ complex for which the structural properties of the light-induced excited HS states are known [9]. In this sample, the HS state is not trapped by flash cooling to $30 \mathrm{~K}$. To explain this difference of behaviour, from a structural approach, we can argue on one intramolecular difference between the $\left[\mathrm{Fe}(\text { phen })_{2}(\mathrm{NCS})_{2}\right]$ and the $\left[\mathrm{Fe}(\mathrm{PM}-\mathrm{BiA})_{2}(\mathrm{NCS})_{2}\right]$ complexes. In the HS state, the Fe-N bond lengtHS are significantly smaller in the former than in the latter and, as a result, the average variation of the six Fe-N bond lengtHS at the SCO is significantly smaller in [Fe(phen $\left.)_{2}(\mathrm{NCS})_{2}\right](0.173 \AA)[28]$ than in $\left.\mathrm{Fe}(\mathrm{PM}-\mathrm{BiA})_{2}(\mathrm{NCS})_{2}\right]$ $(0.235 \AA)$. Consequently, the possibility to thermally trap the HS state may aLSo depend on the intramolecular structural properties of the molecular complex. However, we have recently shown that any relationship between structural and SCO properties must be discussed from a large structural data set [26]. Therefore, complementary investigations appear necessary to clarify this point.

\subsection{Degree of spin state trapping}

The SCO from LS to HS in iron(II) complexes corresponds to an increase of the Fe-N bond lengtHS and a distortion of the octahedron [22]. The first is usually characterised by the average value of the six metal nitrogen distances, noted $d$ here, and the second has been more recently characterised by the $\Sigma$ parameter that is the sum of the deviations from $90^{\circ}$ of the 12 cis $\Phi$ angles in the coordination sphere [5]. The volume of the polyhedron, $V p$, can aLSo be used to characterise the spin state [6]. These parameters are spin state dependent but they are independent of thermal effects. Table 2 reports such parameters for the different crystal structures of polymorph I of $\left[\mathrm{Fe}(\mathrm{PM}-\mathrm{BiA})_{2}(\mathrm{NCS})_{2}\right]$. The values of all these parameters at $30 \mathrm{~K}$ after flash cooling match perfectly, within the standard deviations, the HS room temperature values. Thus, the geometry of the trapped $\mathrm{HS}\left[\mathrm{FeN}_{6}\right]$ octahedron is identical to the room temperature HS one. Without any doubt, the iron(II) complex in the flash cooled crystal structure is in the HS state.

Moreover, the perfect matching of the HS and trapped HS iron octahedron geometry shows that, in this experiment, almost $100 \%$ of the HS species were trapped. In the previously reported investigation performed on other SCO complexes, only a partial ratio of HS species were trapped in the rapid cooling experiments [15 and 16] while an almost complete HS trap was observed by flash cooling [14].

\subsection{Crystal packing}

The general description (Section 2.1) of the packing in the $\left[\mathrm{Fe}(\mathrm{PM}-\mathrm{L})_{2}(\mathrm{NCS})_{2}\right]$ complexes is still true for $\left[\mathrm{Fe}(\mathrm{PM}-\mathrm{BiA})_{2}(\mathrm{NCS})_{2}\right]$ in the trapped HS state at $30 \mathrm{~K}$. However, significant differences from either the room temperature HS or the $30 \mathrm{~K}$ LS crystal structures appear in the crystal packing and thus in the strength of the intermolecular interactions. This is first illustrated by the shortest distance between the centre of two adjacent molecules that is $8.816(1) \AA$ at $293 \mathrm{~K}, 8.836(2) \AA$ at $30 \mathrm{~K}$ in the HS state and 9.065(5) $\AA$ at $30 \mathrm{~K}$ in the LS state. This distance is indeed half of the unit cell $c$ parameter. The longest value in the $30 \mathrm{~K} \mathrm{LS}$ crystal structures is then related to the increase of c due to the SCO. In the HS state crystal packing this distance is slightly longer at $30 \mathrm{~K}$ than at room temperature one, this is due to the anisotropy of the unit cell modifications by flash cooling from 293 to $30 \mathrm{~K}$. Consequences of these differences are reflected by the intermolecular interactions.

The $\pi-\pi$ interactions network in the HS trapped crystal structure appears different from those of the room temperature HS or low temperature LS crystal structures. For example the length of the shortest of such intermolecular interactions is 3.328(10) $\AA$ at $30 \mathrm{~K}$ (HS), $3.355(10) \AA$ at $30 \mathrm{~K}$ (LS) and 3.457(15) $\AA$ at $293 \mathrm{~K}$ (HS). This interaction is then strongly dependent on the temperature and slightly on the spin state.

One of the other main feature of the crystal packing of the $\left[\mathrm{Fe}(\mathrm{PM}-\mathrm{L})_{2}(\mathrm{NCS})_{2}\right]$ complexes concerns a weak hydrogen intermolecular interaction (Fig. 4). Indeed, the $\mathrm{S} \cdots \mathrm{C}$ distance in the $\mathrm{S} \cdots \mathrm{H}-\mathrm{C}$ intermolecular contact between neighbouring molecules differs from one compound to the other and from the HS to the LS states for the same compound. Within the $\left[\mathrm{Fe}(\mathrm{PM}-\mathrm{L})_{2}(\mathrm{NCS})_{2}\right]$ family, such a S ‥C length in the HS state has been directly connected to the propagation of the spin change information, i.e. the cooperativity, over the material during the thermal SCO and thus is a predominant structural feature [26]. This $\mathrm{S} \cdots \mathrm{C}$ intermolecular distance ( Table 3) is much shorter in the $30 \mathrm{~K} \mathrm{HS}$ packing than in the room temperature HS one, indicating that the cooperativity in the former is higher than in the latter. Interestingly, this contact is, at $30 \mathrm{~K}$, shorter in the trapped HS than in the LS crystal packing. For this complex, this S ‥C intermolecular distance is roughly along the $\left[\begin{array}{lll}1 & 3 & 2\end{array}\right]$ crystallographic direction and consequently its length is strongly dependent on the modifications of the $b$ and $c$ unit cell parameters. In the HS state, the difference between the room temperature and the $30 \mathrm{~K} \mathrm{~S} \cdots \mathrm{C}$ distances is then directly linked to the pure thermal effects on the unit cell which correspond to a strong decrease of $b$ from 293 to $30 \mathrm{~K}$. Identically, at the same temperature (30 $\mathrm{K}$ ), the length of this intermolecular interaction is mainly driven by the spin state and thus the increase of $c$ at the HS to LS $\mathrm{SCO}, b$ being almost constant. 


\section{CONCLUSIONS}

To summarise we have shown that it is possible to trap a complex in the HS state by flash cooling. The structural properties of the complex in the low temperature HS state have been determined. We have first shown that, for the studied compound, the low temperature trapped HS state can be obtained only if the final temperature is lower than a temperature similar to the $T$ (LIESST) temperature. Then, this study confirms the anisotropy of the unit cell modifications due to the SCO only and shows the large unit cell volume reduction (4.6\%) from HS to LS. Finally, the crystal structure of the complex in the low temperature HS state appears distinct from either the low temperature LS state or the room temperature HS state crystal structures, this being directly linked to the differences between the unit cell modifications due to a pure thermal contraction and the unit cell modifications due to the SCO.

\section{EXPERIMENTAL}

\subsection{Rapid cooling and flash cooling}

As a preliminary remark we would like to introduce a distinction between a flash cooling experiment and a rapid cooling experiment. The first term refers to a direct shift of a sample from room temperature to the required low temperature; the sample and its support being so small that they do not significantly affect the temperature in the low temperature area. The second one refers either to a very fast controlled cooling rate or to a direct shift from room temperature to a low temperature cavity but with a significant interplay between the temperatures of the sample and its support with the low temperature area. The sample should more rapidly reach the required temperature in a flash cooling experiment than in a rapid cooling experiment. For example, in an X-ray diffraction experiment, a small crystal may be taken directly from room temperature into a nitrogen or an helium flue already at the required temperature. The sample volume is very small and does not introduce a significant perturbation on the flue temperature. It has been demonstrated in the context of the study of large protein crystaLS that a flash cooled sample reaches the final temperature in a maximum of about $1 \mathrm{~s}$ [27]. On the contrary, a true flash cooling experiment is not possible in a squid cavity as, even though the latter is already at the required low temperature, the introduction of the fibre containing the sample inevitably induced a temperature gradient that only allow a rapid cooling experiment, the equilibrium can take a few minutes to achieve [18]. In general, such distinction should be taken in mind when comparing structural with magnetic squid experiment. The X-ray experiments described here refer to flash cooling.

\subsection{Synthesis}

The polymorph I of cis-bis(thiocyanato)bis(N-(2-pyridylmethylene)-aminobiphenyl)-iron (II), [Fe(PM-BiA) $\left.{ }_{2}(\mathrm{NCS})_{2}\right]$ as well as all the $\left[\mathrm{Fe}(\mathrm{PM}-\mathrm{L})_{2}(\mathrm{NCS})_{2}\right]$ complexes discussed in this paper were prepared following the synthetic procedure previously reported [8]. PolymorpHS I and II of [Fe(PM-BiA $\left.)_{2}(\mathrm{NCS})_{2}\right]$ are differentiated by room temperature X-ray diffraciton.

\subsection{X-ray diffraction}

A single crystal of polymorph I of $\left[\mathrm{Fe}(\mathrm{PM}-\mathrm{BiA})_{2}(\mathrm{NCS})_{2}\right]$ was flash cooled to $30 \mathrm{~K}$ and data collection was performed using an Oxford Cryosystems Helix open flow He gas cryostat combined with a Bruker SMART-CCD area detector diffractometer using the Mo K $\alpha$ radiation. The diffraction frames were integrated using the SAINT package. The structural determination by direct methods and the refinement of the atomic parameters based on full-matrix least squares on $\mathrm{F}^{2}$ were performed using the SHELX -97 [28] programs within the WINGX package [29]. H atoms were treated according to the riding model during refinement with isotropic displacement corresponding to the atom they are linked to. Table 1 reports experimental detaiLS and crystal data. Let us make a short comment on the sample temperature after such experiment. Unsurprisingly, the trapped HS and the room temperature $\mathrm{HS} \mathrm{FeN}{ }_{6}$ cores show a difference in the equivalent displacement ellipsoïd parameters, $U_{e q}$, defined as $1 / 3$ of

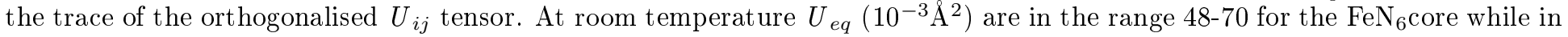
the $30 \mathrm{~K}$ trapped $\mathrm{HS} \mathrm{FeN}{ }_{6}$ core they lay within the range 9-16 (Table 4). Furthermore, in all the slowly cooled crystal structures at $30 \mathrm{~K}$ of complexes, the $U_{\text {eq }}$ displacement ellipsoïd parameters for the $\mathrm{FeN}_{6}$ cores lay within the range 8-16 [5]. This confirms that the sample is indeed at $30 \mathrm{~K}$ and thus that the trapped $\mathrm{HS}$ state has been obtained at $30 \mathrm{~K} \mathrm{n}$ order to investigate the role of the final temperature on the result of the flash cooling experiment, five other single crystaLS of polymorph I were selected. Each of them was successively used in one flash cooled experiment from room temperature to a different temperature using the same protocol than above, a small set of X-ray diffraction frames being then recorded. Final temperatures explored were 140, $95,80,65$ and $30 \mathrm{~K}$. 


\section{REFERENCES}

1. P. Gütlich, A. Hauser and H. Spiering. Angew. Chem. Int. Ed. Engl. 33 (1994), p. 2024.

2. A. Bousseksou, N. Negre, M. Goiran, L. Salmon, J.P. Tuchagues, M.L. Boillot, K. Boukheddaden and F. Varret. Eur. Phys. J. B 13 (2000), p. 451.

3. O. Kahn, J. Kröber and C. Jay. Adv. Mater. 4 (1992), p. 718.

4. P. Guionneau, J.F. Létard, D.S. Yufit, D. Chasseau, G. Bravic, A. Goeta, J.A.K. Howard and O. Kahn. J. Mater. Chem. 9 (1999), p. 985.

5. P. Guionneau, C. Brigouleix, Y. Barrans, A. Goeta, J.F. Létard, J.A.K. Howard, J. Gaultier and D. Chasseau. C.R. Acad. Sci. IIc (2001), p. 161.

6. P. Guionneau, M. Marchivie, G. Bravic, J.F. Létard and D. Chasseau. J. Mater. Chem. 12 (2002), p. 2546.

7. J.F. Létard, P. Guionneau, E. Codjovi, O. Lavastre, G. Bravic, D. Chasseau and O. Kahn. J. Am. Chem. Soc. 119 (1997), p. 10861.

8. J.F. Létard, P. Guionneau, L. Rabardel, J.A.K. Howard, A. Goeta, D. Chasseau and O. Kahn. Inorg. Chem. 37 (1998), p. 4432.

9. M. Marchivie, P. Guionneau, J.A.K. Howard, A. Goeta, G. Chastanet, J.F. Létard and D. Chasseau. J. Am. Chem. Soc. 124 (2002), p. 194.

10. P. Decurtins, P. Gütlich, K.M. Hasselbach, A. Hauser and H. Spiering. Inorg. Chem. 24 (1985), p. 2174.

11. A. Hauser. Chem. Phys. Lett. 124 (1986), p. 543.

12. P. Gütlich, Y. Garcia and T. Woike. Coord. Chem. Rev. 219 (2001), p. 839.

13. T. Buchen, P. Gütlich and H.A. Goodwin. Inorg. Chem. 33 (1994), p. 4573.

14. T. Buchen, P. Gütlich, K.H. Sugiyarto and H.A. Goodwin. Chem. Eur. J. 2 (1996), p. 1134.

15. H.A. Goodwin and K.H. Sugiyarto. Chem. Phys. Lett. 139 (1987), p. 470.

16. G. Ritter, E. König, W. Irler and H.A. Goodwin. Inorg. Chem. 17 (1978), p. 224.

17. A.F. Stassen, O. Roubeau, I. Ferrero Gramage, J. Linarès, F. Varret, I. Mutikainen, U. Turpeinen, J.G. Haasnot and J. Reedijk. Polyhedron 20 (2001), p. 1699.

18. Z. Yu, K. Liu, J.Q. Tao, Z.J. Zhong, X.Z. You and G.G. Siu. J. Appl. Phys. Lett. 74 (1999), p. 4029.

19. O. Roubeau, M. deVos, A.F. Stassen, R. Burriel, J.G. Haasnot and J. Reedjik. J. Phys. Chem. Sol. 64 (2003), p. 1003.

20. J.F. Létard, L. Capes, G. Chastanet, N. Moliner, S. Létard, A. Real and O. Kahn. Chem. Phys. Lett. 313 (1999), p. 115.

21. J.F. Létard, G. Chastanet, O. Nguyen, S. Marcén, M. Marchivie, P. Guionneau, D. Chasseau and P. Gütlich. Monatshefte für Chemie 134 (2003), p. 165.

22. E. König. Prog. Inorg. Chem. 35 (1987), p. 527.

23. H. Daubric, J. Kliava, P. Guionneau, D. Chasseau, J.F. Létard and O. Kahn. J. Phys.: Condens. Matter 12 (2000), p. 5481.

24. E. Wiehl, H. Spiering, P. Gütlich and K. Knorr. J. Appl. Crystallogr. 23 (1990), p. 151.

25. J. Kusz, H. Spiering and P. Gütlich. J. Appl. Crystallogr. 34 (2001), p. 229.

26. P. Guionneau, M. Marchivie, G. Bravic, J.F. Létard and D. Chasseau. Topics Curr. Chem. (2003) in press .

27. T.-Y. Teng and K. Moffat. J. Appl. Crystallogr. 31 (1998), p. 252.

28. G.M. Sheldrick, D-3400 Göttingen, Germany, 1998.

29. L.J. Farrugia. J. Appl. Crystallogr. 32 (1999), p. 837. 
Figure 1.

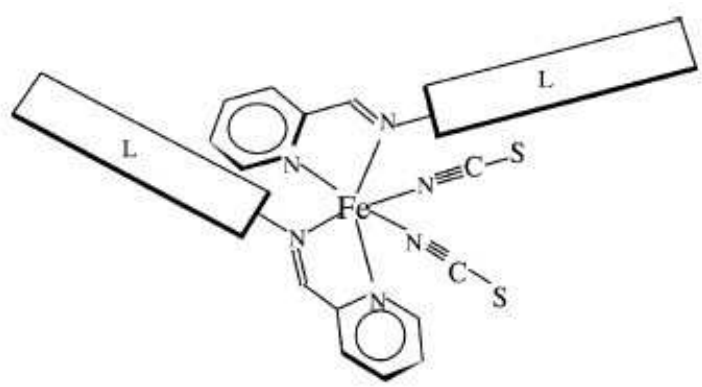

(a)

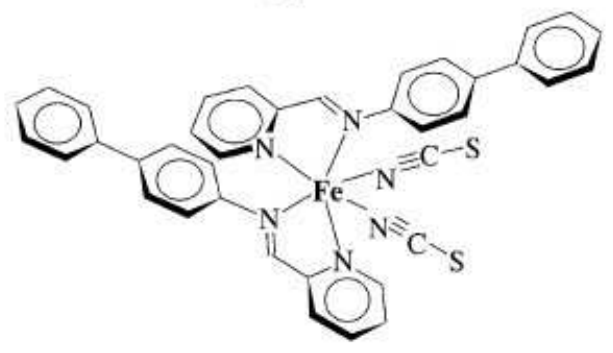

(b)

Fig. 1. Schematic representation of the $\left[\mathrm{Fe}(\mathrm{PM}-\mathrm{L})_{2}(\mathrm{NCS})_{2}\right]$ complexes (a) and of the studied complex $\left[\mathrm{Fe}(\mathrm{PM}-\mathrm{BiA})_{2}(\mathrm{NCS})_{2}\right]$ in particular (b).

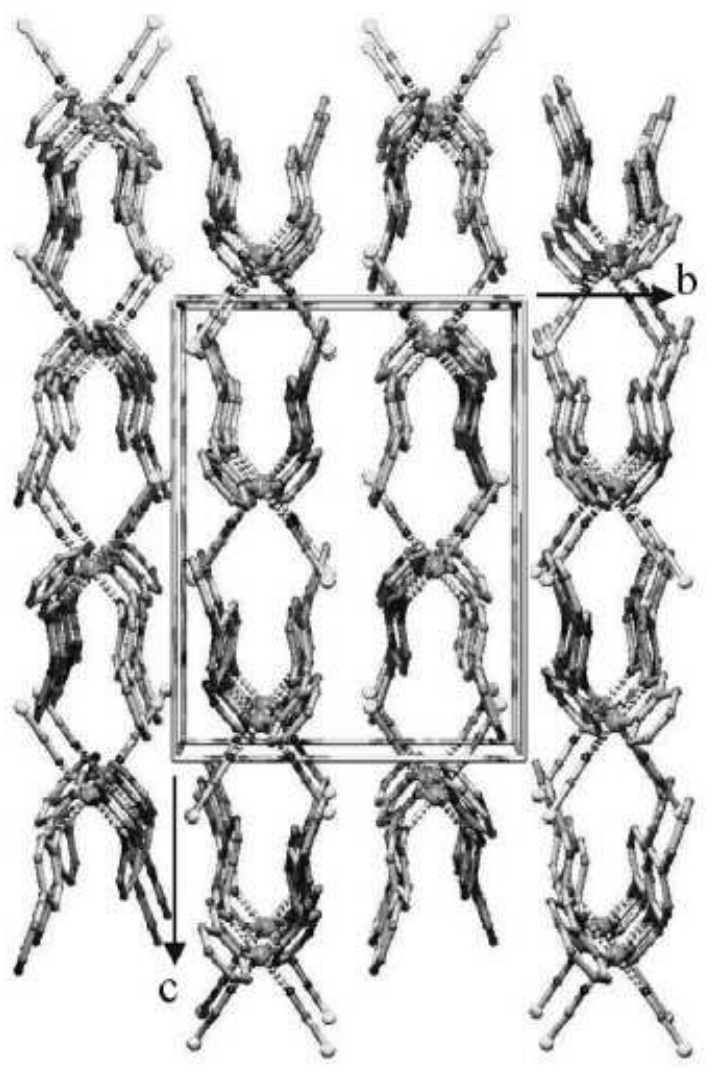

Fig. 2. View along $a$ of the molecular packing in polymorph $I$ of $[\mathrm{Fe}(\mathrm{PM}-$ $\mathrm{BiA})_{2}(\mathrm{NCS})_{2}$.

Figure 2. 
Table 1.

Table 1

X-ray diffraction experimental and crystal data for polymorph I of $\left[\mathrm{Fe}(\mathrm{PM}-\mathrm{BiA})_{2}(\mathrm{NCS})_{2}\right]$

\begin{tabular}{|c|c|c|c|}
\hline Chemical formula & & $\mathrm{C}_{38} \mathrm{H}_{28} \mathrm{Fe}_{1} \mathrm{~N}_{6} \mathrm{~S}_{2}$ & \\
\hline Ref. & This work & [5] & [7] \\
\hline Morphology & \multicolumn{3}{|c|}{$\begin{array}{l}\text { Black prism of approx, dim. } \\
0.20 \times 0.15 \times 0.15 \mathrm{~mm}^{3}\end{array}$} \\
\hline$T(\mathrm{~K})$ & 30 & 30 & 293 \\
\hline Cooling rate & Flash cooled & $3 \mathrm{~K} \mathrm{~min}^{-1}$ & - \\
\hline Spin state & HS & LS & HS \\
\hline Space group & Pccn & Pccn & Pccn \\
\hline Z-formula & 4 & 4 & 4 \\
\hline a & $12.964(1)$ & $12.224(3)$ & $12.977(1)$ \\
\hline b & $14.712(1)$ & $14.484(4)$ & $15.211(1)$ \\
\hline c & $17.672(2)$ & $18.130(5)$ & $17.633(1)$ \\
\hline V & $3370(1)$ & $3210(1)$ & $3481(1)$ \\
\hline Nb. refl. col. & 20,719 & - & - \\
\hline Nb. refl, indep. & 3823 & - & - \\
\hline$R_{\text {int }}$ & 0.10 & - & - \\
\hline Ref. on & $F^{2}$ & - & - \\
\hline Ref, parameter & 268 & & \\
\hline$R_{\mathrm{chs}}$ & 0.055 & 0.068 & 0.045 \\
\hline$w R 2_{\alpha \mathrm{s}}$ & 0.098 & 0.154 & - \\
\hline$(\Delta / \sigma)_{\max }$ & 0.001 & - & - \\
\hline$\Delta \rho\left(\mathrm{e}^{-} \mathrm{A}^{-3}\right)$ & $+0.4 /-0.6$ & - & - \\
\hline
\end{tabular}

Table 2

Table 2

$\mathrm{FeN}_{6}$ octahedron geometry in polymorph $\mathrm{I}$ of $\left[\mathrm{Fe}(\mathrm{PM}-\mathrm{BiA})_{2}(\mathrm{NCS})_{2}\right]$ as a function of the spin state and of the cooling mode (see text for definition)

\begin{tabular}{lllll}
\hline$T(\mathrm{~K})$ & 293 & 140 & 30 & 30 \\
Cooling rate & - & $3 \mathrm{~K} \mathrm{~min}^{-1}$ & $3 \mathrm{~K} \mathrm{~min}^{-1}$ & Flash cooled \\
Spin state & HS & LS & LS & HS \\
$d_{\mathrm{Fe}-\mathrm{N}}(\hat{\mathrm{A}})$ & 2.174 & 1.956 & 1.939 & 2.180 \\
$\Sigma\left({ }^{\circ}\right)$ & 86 & 48 & 50 & 90 \\
$V_{\mathrm{p}}\left(\hat{\mathrm{A}}^{3}\right)$ & 13.1 & 9.9 & 9.7 & 13.2 \\
\hline
\end{tabular}

Standard deviations are $0.003 \AA$ for $d_{\mathrm{Fe}-\mathrm{N}}, 2^{\circ}$ for $\Sigma, 0.2 \AA^{3}$ for $V_{\mathrm{p}}$. 
Figure 3 .

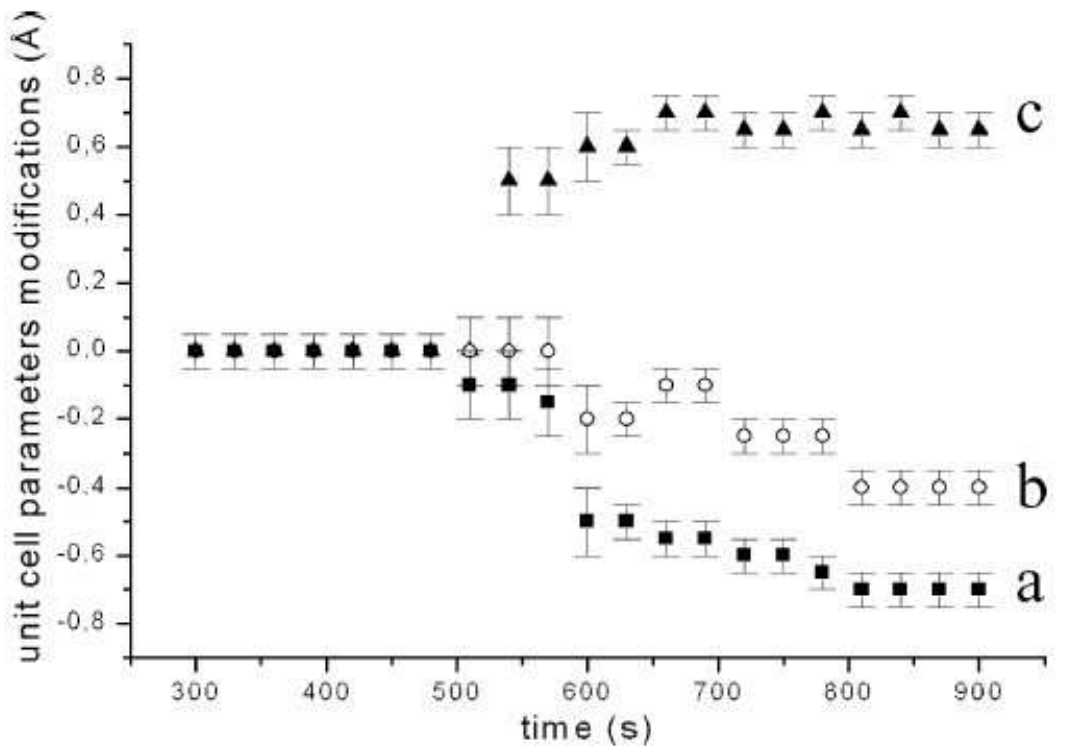

Fig. 3. Crystallographic unit cell parameters modifications $(\AA)$ as a function of time at $80 \mathrm{~K}$ after flash cooling showing the HS $\rightarrow$ LS relax ation, a parameter (full square), $b$ parameter (open square), $c$ parameter (triangle).

Figure 4.

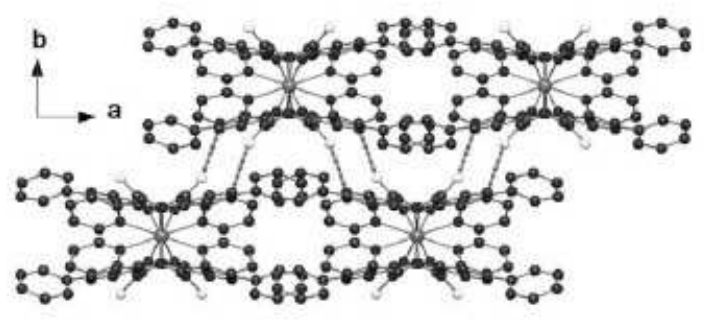

Fig. 4. View of the shortest hydrogen like S. . H-C intermolecular contact in polymorph $\mathrm{I}$ of $\left[\mathrm{Fe}(\mathrm{PM}-\mathrm{BiA})_{2}(\mathrm{NCS})_{2}\right]$.

Table 3.

Table 3

Structural parameters that defined the intermolecular hydrogen bond $\mathrm{S} \cdot \mathrm{H}-\mathrm{C}$ in polymorph $\mathrm{I}$ of $\left[\mathrm{Fe}(\mathrm{PM}-\mathrm{BiA})_{2}(\mathrm{NCS})_{2}\right]$ as a function of the spin state and of the cooling mode

\begin{tabular}{llllll}
\hline$T(\mathrm{~K})$ & Spin state & $\mathrm{S} \cdots \mathrm{C}(\AA)$ & $\mathrm{S} \cdots \mathrm{H}(\AA)$ & $\mathrm{S} \cdots \mathrm{H}-\mathrm{C}(\boldsymbol{)})$ & $\mathrm{C}-\mathrm{S} \cdots \mathrm{H}(\mathrm{\rho})$ \\
\hline$\sigma_{\max }$ & & 0.010 & 0.02 & 1 & 1 \\
293 & HS & 3.414 & 2.81 & 115 & 146 \\
30 & HS & 3.360 & 2.77 & 118 & 145 \\
30 & LS & 3.378 & 2.77 & 125 & 156 \\
\hline
\end{tabular}


Table 4.

Table 4

Fractional atomic coordinates $\left(10^{-4}\right)$ and equivalent isotropic displacement parameters $\left(10^{-3} \mathrm{~A}^{2}\right)$ for polymorph I of $\left[\mathrm{Fe}(\mathrm{PM}-\mathrm{BiA})_{2}(\mathrm{NCS})_{2}\right]$ after a flash cooling at $30 \mathrm{~K}$

\begin{tabular}{|c|c|c|c|c|}
\hline & $x$ & $y$ & $z$ & $U($ eq) \\
\hline $\mathrm{Fe}(1)$ & 7500 & 2500 & $793(1)$ & $9(1)$ \\
\hline$S(1)$ & $9176(1)$ & $4438(1)$ & $-1045(1)$ & $16(1)$ \\
\hline $\mathrm{N}(1)$ & $7474(2)$ & $1532(2)$ & $1775(2)$ & $12(1)$ \\
\hline $\mathrm{N}(2)$ & $9125(2)$ & $2046(2)$ & $958(1)$ & $12(1)$ \\
\hline $\mathrm{N}(3)$ & $8017(2)$ & $3410(2)$ & $-13(2)$ & $14(1)$ \\
\hline $\mathrm{C}(4)$ & $2879(3)$ & $1332(2)$ & $3293(2)$ & $14(1)$ \\
\hline$C(5)$ & $6594(3)$ & $1366(2)$ & $2242(2)$ & $11(1)$ \\
\hline$C(6)$ & $6634(3)$ & $1466(2)$ & $3026(2)$ & $13(1)$ \\
\hline$C(8)$ & $4796(3)$ & $1153(2)$ & $3107(2)$ & $13(1)$ \\
\hline$C(9)$ & $5657(3)$ & $1153(2)$ & $1885(2)$ & $12(1)$ \\
\hline $\mathrm{C}(10)$ & $4767(3)$ & $1052(2)$ & $2318(2)$ & $11(1)$ \\
\hline$C(11)$ & $5738(3)$ & $1353(2)$ & $3451(2)$ & $14(1)$ \\
\hline $\mathrm{C}(12)$ & $10,958(3)$ & $2039(2)$ & $743(2)$ & $16(1)$ \\
\hline$C(13)$ & $1980(3)$ & $1204(2)$ & $3708(2)$ & $17(1)$ \\
\hline $\mathrm{C}(14)$ & $10,268(3)$ & $1238(2)$ & $1801(2)$ & $15(1)$ \\
\hline C(15) & $8358(3)$ & $1263(2)$ & $2004(2)$ & $13(1)$ \\
\hline$C(16)$ & $11,112(3)$ & $1504(2)$ & $1379(2)$ & $15(1)$ \\
\hline $\mathrm{C}(17)$ & $9287(3)$ & $1517(2)$ & $1578(2)$ & $13(1)$ \\
\hline C(18) & $2964(3)$ & $435(2)$ & $4676(2)$ & $15(1)$ \\
\hline C(19) & $3837(3)$ & $1020(2)$ & $3561(2)$ & $12(1)$ \\
\hline $\mathrm{C}(20)$ & $9954(3)$ & $2290(2)$ & $553(2)$ & $12(1)$ \\
\hline$C(21)$ & $2023(3)$ & $748(2)$ & $4400(2)$ & $17(1)$ \\
\hline $\mathrm{C}(22)$ & $3863(3)$ & $571(2)$ & $4261(2)$ & $15(1)$ \\
\hline $\mathrm{C}(1)$ & $8498(3)$ & $3832(2)$ & $-449(2)$ & $12(1)$ \\
\hline
\end{tabular}

$U(e q)$ is defined as one third of the trace of the orthogonalized $U_{i j}$ tensor. 